\title{
Estimation of substrate-energetic fluxes in lactating cows $^{*}$
}

\author{
G.G. Cherepanov ${ }^{1}$ and V.I. Agaphonov \\ Institute of Physiology, Biochemistry and Nutrition of Farm Animals, \\ Russian Academy of Agricultural Sciences \\ Borovsk-3, Kaluga Region, 249013, Russia
}

(Received 16 April 2009; revised version 3 November 2009; accepted 29 January 2010)

\begin{abstract}
In this article an algorithm estimating the basic metabolic fluxes in lactating cows is described that uses data of substrates absorption, heat production, respiratory quotient and milk productivity. The flux diagram permits to estimate parameters which are very difficult to measure in physiological experiments, including rates of oxidation of substrates to $\mathrm{CO}_{2}$ and their interconversions (synthesis of long-chain fatty acids from acetate, gluconeogenesis from amino acids, etc.). The developed model was verified in an experiment carried out on two groups of lactating cows with measurements of energy balance, heat production and respiratory quotient $\left(\mathrm{CO}_{2} / \mathrm{O}_{2}\right)$ during the periods of 40-45, 60-65 and 90-95 days of lactation. The estimates of oxidation rates obtained for amino acids, glucose, long chain fatty acids and acetate do agree with literature data. The analysis of combined data revealed a negative correlation between oxidation rates of glucose and acetate $(\mathrm{r}=0.91)$ and between substrate groups (long chain fatty acids + butyrate) and (glucose + acetate $)(r=0.75)$.
\end{abstract}

KEY WORDS: dairy cows, heat production, metabolic fluxes, oxidation rates, computational algorithm

\section{INTRODUCTION}

The future generations of feeding systems for productive ruminants will have to be based on the quantitative prediction of absorption fluxes of main nutrients, their partitioning in the organism and the formation of energy and substance

\footnotetext{
* Supported by the Russian Foundation of Basic Research, Project No. 08-04-13577

${ }^{1}$ Corresponding author: e-mail: znm@borovsk.ru
} 
balances taking into account the influence of environmental factors. The principal possibility of the development and refinement of mechanistic metabolic models was evidenced (Baldwin et al., 1987; Danfaer, 1990; Hanigan et al., 2004), but for their practical use they have to be more sophisticated and adapted to various genotypes and nutritional states. Therefore, methods should be developed to obtain quantitative experimental data needed for parametrization and verification of the mechanistic models of intermediary metabolism. Energy criteria and parameters are primarily needed to be refined since they express in an integral form the characteristics of nutrient balances that are governed by the law of energy conservation (Baldwin and Bywater, 1984). In particular, the respiratory measurements may be used for verification of estimated balance of individual energy substrates metabolized at the tissue level. While the use of respiration chambers is too expensive and cumbersome, the face mask method allows to perform serial measurements needed for practical diets (Brosh, 2008). The goal of this report was to develop an algorithm for computing the basic metabolic fluxes in lactating cows with the use of experimental data of substrates absorption, respiratory measurements and productive traits (milk component yields, accretion or mobilization of fat depot).

\section{MATERIAL AND METHODS}

As material for analysis, experimental data were used which were obtained in a trial performed on eight multiparous cows that at day 20 before calving were assigned to 2 groups and the experimental group was fed a ration with increased energy concentration. From day 10 of lactation the cows of the two groups were fed rations with various ratios of degradable and non-degradable protein and starch (Table 1). The heat production was measured by the method of indirect calorimetry in respiratory trials using face masks. The rumen fluid was obtained using oesophageal probe. The feasibility of this method was substantiated by comparing the results with the data obtained on cannulated animals. The details of the experiment are described elsewhere (Agaphonov and Denkin, 2009). The parameters measured in the experiment and estimated indirectly are presented in Tables 2 and 4, respectively.

The daily absorption fluxes of amino acids were calculated as sum of NDP $\times$ $0.7+\mathrm{DP} \times 0.56$, where NDP and DP are non-degradable and degradable protein intake $(\mathrm{g} / \mathrm{d})$. The VFA production was calculated on the basis of estimated energy value of nutrients digested in the rumen, taking into account the energy losses (25\%) during fermentation (Agaphonov, 1998) (Table 3), and measured molar ratios of VFA in the rumen fluid. The daily absorption fluxes of free long-chain fatty acids (FFA) were calculated as content of crude fat in ration multiplied by 
Table 1. The main ingredients and chemical composition of rations ${ }^{1}$

\begin{tabular}{|c|c|c|c|c|c|c|c|c|}
\hline \multirow{3}{*}{ Items } & \multirow{2}{*}{\multicolumn{2}{|c|}{$\begin{array}{c}\begin{array}{c}\text { Dry period, } d \\
\text { before calving }\end{array} \\
-20-0 \\
\end{array}$}} & \multicolumn{6}{|c|}{ Periods, days in milk } \\
\hline & & & \multicolumn{2}{|c|}{$10-45$} & \multicolumn{2}{|c|}{$46-65$} & \multicolumn{2}{|c|}{$66-95$} \\
\hline & I & II & $\mathrm{I}$ & II & $\mathrm{I}$ & II & I & II \\
\hline \multicolumn{9}{|l|}{ Ingredients, $\mathrm{kg}$} \\
\hline hay of astragal & 4 & 4 & 3.7 & 3.9 & 3.6 & 3.3 & 3.9 & 3.3 \\
\hline vetch-oat silage & 14 & 10 & 20.4 & 20.4 & 18.3 & 19.9 & 20.3 & 20.9 \\
\hline molasses & - & - & 1.0 & 1.0 & 0.8 & 0.8 & - & - \\
\hline concentrates & 2 & 4 & 9.0 & 9.0 & 9.0 & 10.0 & 8.0 & 10.0 \\
\hline \multicolumn{9}{|l|}{ Daily intake } \\
\hline $\mathrm{ME}, \mathrm{MJ}$ & 101 & 105 & 145 & 163 & 158 & 182 & 153 & 178 \\
\hline $\mathrm{DM}, \mathrm{kg}$ & 11.2 & 11.2 & 17.6 & 17.7 & 17.6 & 19.5 & 17.6 & 19.3 \\
\hline $\mathrm{CP}, \mathrm{g}$ & 1520 & 1620 & 2465 & 2732 & 3070 & 3245 & 2675 & 3010 \\
\hline DP, $g$ & 1050 & 1134 & 1495 & 1500 & 1750 & 1870 & 1790 & 2020 \\
\hline NDP, $g$ & 470 & 486 & 775 & 1002 & 1000 & 1055 & 885 & 990 \\
\hline $\mathrm{CF}, \mathrm{g}$ & 2970 & 2610 & 3319 & 3448 & 3984 & 4268 & 3673 & 3878 \\
\hline starch, $\mathrm{g}$ & 906 & 1686 & 3880 & 3600 & 3650 & 3600 & 3010 & 3725 \\
\hline sugar, g & 262 & 300 & 1065 & 1390 & 900 & 935 & 390 & 455 \\
\hline crude fat, $g$ & 323 & 330 & 440 & 470 & 488 & 518 & 330 & 434 \\
\hline
\end{tabular}

I I - control group; II - experimental group; ME - metabolizable energy; CP - crude protein; DP - degradable protein; NDP - non-degradable protein; CF - crude fibre

Table 2. Milk yield, milk composition and parameters of the energy metabolism measured in the experiment ${ }^{1}$

\begin{tabular}{lcccccccc}
\hline Periods, & $\begin{array}{c}\text { Milk yield } \\
\mathrm{kg} / \mathrm{d}\end{array}$ & $\begin{array}{c}\text { Fat } \\
\text { Groups }\end{array}$ & $\begin{array}{c}\text { Protein } \\
\%\end{array}$ & $\begin{array}{c}\text { Lactose } \\
\mathrm{g} / \mathrm{d}\end{array}$ & $\begin{array}{c}\text { ME } \\
\text { MJ }\end{array}$ & \multicolumn{1}{c}{$\begin{array}{c}\text { HP } \\
\text { MJ }\end{array}$} & $\begin{array}{c}\text { Energy } \\
\text { balance MJ }\end{array}$ & RQ \\
\hline 1 - control & 18.7 & 3.90 & 3.46 & 898 & 145.5 & 92.1 & -5.8 & 0.867 \\
1 - experimental & 24.0 & 3.51 & 3.33 & 1152 & 162.7 & 95.9 & -6.6 & 0.871 \\
2 - control & 20.1 & 3.26 & 3.29 & 965 & 158.7 & 94.3 & 2.8 & 0.878 \\
2 - experimental & 25.8 & 3.32 & 3.29 & 1238 & 182.1 & 100.1 & 1.9 & 0.850 \\
3 - control & 17.9 & 3.51 & 3.48 & 859 & 153.3 & 98.2 & 6.2 & 0.840 \\
3 - experimental & 24.8 & 3.63 & 3.23 & 1190 & 178.1 & 107.8 & 2.1 & 0.831 \\
\hline
\end{tabular}

${ }^{1}$ the measurements were carried out during 3 periods $1: 40-45 ; 2: 60-65 ; 3: 90-95$ days in milk; $\mathrm{ME}$ - metabolizable energy; $\mathrm{HP}$ - heat production; RQ - respiratory quotient $\left(\mathrm{CO}_{2} / \mathrm{O}_{2}\right)$

Table 3. The mean percentage values of the energy digested and lost in the rumen ${ }^{1}$

\begin{tabular}{|c|c|c|c|c|c|c|}
\hline \multicolumn{3}{|c|}{$\begin{array}{l}\text { The composition of rations } \\
\% \text { of } \mathrm{ME}\end{array}$} & \multicolumn{2}{|c|}{$\begin{array}{c}\text { Portion of digested } \\
\text { energy, } \%\end{array}$} & \multicolumn{2}{|c|}{$\begin{array}{l}\text { The energy losses during } \\
\text { fermentation in rumen }\end{array}$} \\
\hline forages & $\begin{array}{l}\text { beet, potato, } \\
\text { molasses }\end{array}$ & concentrates & in rumen & $\begin{array}{l}\text { in small } \\
\text { intestine }\end{array}$ & $\begin{array}{c}\% \text { of energy } \\
\text { digested in rumen }\end{array}$ & $\begin{array}{c}\% \text { of total } \\
\text { digestible energy }\end{array}$ \\
\hline$\overline{55}$ & 5 & 40 & 70 & 30 & 25 & 18.0 \\
\hline 50 & 5 & 45 & 69 & 31 & 25 & 17.7 \\
\hline 45 & 5 & 50 & 68 & 32 & 25 & 17.5 \\
\hline 40 & 5 & 55 & 67 & 33 & 25 & 17.2 \\
\hline 35 & 5 & 60 & 66 & 34 & 25 & 17.0 \\
\hline 30 & 5 & 65 & 65 & 35 & 25 & 16.7 \\
\hline
\end{tabular}

${ }^{1}$ the data were obtained previously in physiological trials with the use of animals fitted with duodenal and ileo-caecal anastomoses, fed the rations of various composition (Agaphonov, 1998) 
Table 4. The estimated daily absorption fluxes, $g / \mathrm{d}^{1}$

\begin{tabular}{lcccccc}
\hline $\begin{array}{l}\text { Periods, } \\
\text { Groups }\end{array}$ & Amino acids & FFA $^{2}$ & Glucose & Acetate & Propionate & Butyrate \\
\hline 1 - control & 1380 & 370 & 1017 & 3475 & 963 & 708 \\
1 - experimental & 1540 & 395 & 887 & 3823 & 987 & 763 \\
2 - control & 1680 & 410 & 370 & 3775 & 1080 & 775 \\
- experimental & 1785 & 435 & 790 & 4320 & 1275 & 890 \\
3 - control & 1620 & 280 & 600 & 3525 & 1065 & 1110 \\
3 - experimental & 1825 & 365 & 855 & 4190 & 1160 & 1290 \\
\hline
\end{tabular}

${ }^{1}$ the designation of groups and periods see Table $2 ;{ }^{2}$ long-chain fatty acids

0.84. The glucose absorption fluxes were estimated from the difference between digestible energy intake and the sum of energetic value of absorption fluxes of amino acids, VFA and FFA.

The components of heat production for the main groups of oxidizing substrates were estimated using a procedure composed of three steps: 1. measurements of the volume of oxygen uptake, volume of carbon dioxide release, the quantity of the oxidized amino acids (in the most simple version, on the basis of a quantity of urea nitrogen excreted with the urine) and milk components yield in physiological experiments; 2 . calculation of respiratory quotient (RQ) and total heat production (HP); 3. calculation of the components of heat production using RQ. The utilization and oxidation fluxes $(\mathrm{g} / \mathrm{d})$ for main group of substrates were estimated as described in the following section.

\section{RESULTS AND DISCUSSION}

The values of RQ for various substrates were calculated on the basis of stoichiometric equations for their full oxidation to $\mathrm{CO}_{2}$ and $\mathrm{H}_{2} \mathrm{O}$ (Table 5). According to their values of $\mathrm{RQ}$, the main energetic nitrogen free substrates may be subdivided into two groups: FFA, butyrate $(\mathrm{RQ} \approx 0.7)$ and acetate, propionate, glucose, ketone bodies ( $\beta$-hydroxybutyrate, acetoacetate) $(\mathrm{RQ} \approx 1.0)$. Since ketone bodies produced from butyrate and amino acids may be considered as intermediates of their oxidation to $\mathrm{CO}_{2}$ and $\mathrm{H}_{2} \mathrm{O}$, in calculations of the sum of the heat effect of full oxidation of butyrate and amino acids, according to the rule of Hess, the partial heat effects of ketone bodies need not be considered in explicit form. Absorption fluxes of lactate were not measured in the experiment, but taking into account that rumen production of VFA was estimated on the basis of energetic balance in the rumen, lactate production would be included in the calculated fluxes of propionate (these $\mathrm{C} 3$-substrates are the precursors of glucose in ruminants). 
Table 5. The calculation of respiratory quotient (RQ) for several main energetic substrates

\begin{tabular}{|c|c|c|c|}
\hline Substrate & M & $\begin{array}{l}\text { Stoichiometric equation } \\
\text { for full oxidation }\end{array}$ & RQ \\
\hline Glucose, $\mathrm{C}_{6} \mathrm{H}_{12} \mathrm{O}_{6}$ & 180 & $\mathrm{C}_{6} \mathrm{H}_{12} \mathrm{O}_{6}+6 \mathrm{O}_{2}=6 \mathrm{CO}_{2}+6 \mathrm{H}_{2} \mathrm{O}$ & $6 / 6=1.0$ \\
\hline Lactate, $\mathrm{CH}_{3} \mathrm{CH}(\mathrm{OH}) \mathrm{COOH}$ & 90 & $\mathrm{C}_{3} \mathrm{H}_{6} \mathrm{O}_{3}^{\circ}+3 \mathrm{O}_{2}=3 \mathrm{CO}_{2}+3 \mathrm{H}_{2} \mathrm{O}$ & $3 / 3=1.0$ \\
\hline Acetate, $\mathrm{CH}_{3} \mathrm{COOH}$ & 60 & $\mathrm{C}_{2} \mathrm{H}_{4} \mathrm{O}_{2}+2 \mathrm{O}_{2}=2 \mathrm{CO}_{2}+2 \mathrm{H}_{2} \mathrm{O}$ & $2 / 2=1.0$ \\
\hline Propionate, $\mathrm{CH}_{3} \mathrm{CH}_{2} \mathrm{COOH}$ & 74 & $2 \mathrm{C}_{3} \mathrm{H}_{6} \mathrm{O}_{2}+7 \mathrm{O}_{2}=6 \mathrm{CO}_{2}+6 \mathrm{H}_{2} \mathrm{O}$ & $6 / 7=0.86$ \\
\hline Butyrate, $\mathrm{CH}_{3} \mathrm{CH}_{2} \mathrm{CH}_{2} \mathrm{COOH}$ & 88 & $\mathrm{C}_{4} \mathrm{H}_{8} \mathrm{O}_{2}+5 \mathrm{O}_{2}=4 \mathrm{CO}_{2}+4 \mathrm{H}_{2} \mathrm{O}$ & $4 / 5=0.8$ \\
\hline $\begin{array}{l}\beta \text {-hydroxybutyrate, } \\
\qquad \mathrm{CH}_{3} \mathrm{CH}(\mathrm{OH}) \mathrm{CH}_{2} \mathrm{COOH}\end{array}$ & 104 & $2 \mathrm{C}_{4} \mathrm{H}_{8} \mathrm{O}_{3}+9 \mathrm{O}_{2}=8 \mathrm{CO}_{2}+8 \mathrm{H}_{2} \mathrm{O}$ & $8 / 9=0.9$ \\
\hline Acetoacetate, $\mathrm{CH}_{3} \mathrm{COCH}_{2} \mathrm{COOH}$ & 102 & $\mathrm{C}_{4} \mathrm{H}_{6} \mathrm{O}_{3}+4 \mathrm{O}_{2}=4 \mathrm{CO}_{2}+8 \mathrm{H}_{2} \mathrm{O}$ & $4 / 4=1.0$ \\
\hline Palmitic acid, $\mathrm{C}_{15} \mathrm{H}_{31} \mathrm{COOH}$ & 256 & $\mathrm{C}_{16} \mathrm{H}_{32} \mathrm{O}_{2}+24 \mathrm{O}_{2}=16 \mathrm{CO}_{2}+16 \mathrm{H}_{2} \mathrm{O}$ & $16 / 24=0.67$ \\
\hline
\end{tabular}

The measurement of oxidation losses of amino acids in lactating cows presents a difficult task and the direct experimental data have been described earlier by Black et al. (1990). Therefore, for routine analysis the approximate estimation may be used based on the measurements of $\mathrm{N}$ losses with urine.

The utilization of endogenous urea by the gastrointestinal tract in ruminants fed practical diets comprises $40-60 \%$ of its production by the liver (Huntington et al., 1996). The contribution of absorbed $\mathrm{NH}_{3}-\mathrm{N}$ to urea-N produced by the liver under these nutritional conditions is in the range 60-70\% (Riis et al., 1990; Whitt et al., 1996; Tan and Murphy, 2004). If, on the average, urea recirculation is $50 \%$ and the contribution of absorbed $\mathrm{NH}_{3}-\mathrm{N}$ to urea- $\mathrm{N}$ is $65 \%$, then the urea- $\mathrm{N}$ excretion exceeds the oxidation losses of amino acids nitrogen by $23 \%$ $(55 / 65=0.77)$. Taking this into account, the oxidation losses of amino acids can be estimated, in the first approximation, on the basis of urea excretion multiplied by a coefficient which, according to estimates made for practical diets, is 0.7 on the average. In the cases with more intensive utilization of endogenous urea or with increased ruminal $\mathrm{NH}_{3}$ production which can be observed on some rations, the deviations from this average values will be increased. When, as in this paper, the calculation is based on total urine $\mathrm{N}$, this coefficient must be further diminished, so in the following estimates the sum coefficient $0.525(=0.7 \times 0.75)$ was used. Since the contribution of amino acids oxidation to total heat production is relatively small (15\% on the average), the inaccuracies in these estimates of amino acids oxidation may not exert a significant influence on the calculated ratios of other $\mathrm{N}$-free energetic substrates.

In this paper the following values of energetic equivalents (the heat of combustion, $\mathrm{kJ} / \mathrm{g}$ ) were used for main substrate groups: amino acids (on the average) - 23.94, long-chain fatty acids - 38.94, glucose - 16.12, acetate - 14.65 , butyrate - 24.9. The heat production (HP) of amino acids oxidation is equal to the estimated value of oxidation daily losses of amino acids (g) times 23.94. The HP of amino acids oxidation in the organism is slightly smaller compared to the 
heat of their combustion, since $\mathrm{NH}_{3}$ is used in the urea formation cycle, but taking into account the relatively small value of heat of $\mathrm{NH}_{3}$ combustion $(13 \mathrm{~kJ} / \mathrm{mol})$ in the following calculations it was ignored. So, the oxidation losses of amino acids $(\mathrm{g} / \mathrm{d})$ were determined as follows: the total urine $\mathrm{N}(\mathrm{g} / \mathrm{d})$ was multiplied by 0.75 , transformed to crude protein $(\times 6.25)$ and multiplied by 0.7 . The HP of amino acids oxidation is equal to this estimate times 23.94 ("protein HP"). The value of "non-protein HP" was calculated by subtracting "protein HP" from measured total HP.

The contribution of the oxidation of the first group of $\mathrm{N}$-free substrates (FFA+butyrate) to the value of "non-protein HP" $\left(a_{\text {FFA }+ \text { but }}\right)$ was calculated using the equation (the coefficients are the values of "a" and " $b$ " in equation $y=a+b x$, determined by two points, i.e. 0,1 and 1, 0.7: $0=\mathrm{a}+\mathrm{b} \times 1.0$ and $1=\mathrm{a}+\mathrm{b} \times 0.7$ ):

$$
\mathrm{a}_{\text {FFA+but }}=3.33-3.33 \mathrm{RQ}
$$

Generally, in this equation the measured RQ must be corrected for production of $\mathrm{CO}_{2}$ and utilization of $\mathrm{O}_{2}$ in accordance with estimated oxidation losses of amino acids, but preliminary analysis has indicated that the error due to the use of non-corrected RQ is significant only on the end of a range $0.7-1.0$; therefore, in the following calculations the correction of RQ was ignored. The heat effect of the oxidation of the second group of $\mathrm{N}$-free substrates (mainly glucose+acetate) is $\left(1-\mathrm{a}_{\mathrm{FFA}+\text { but }}\right) \times$ "non-protein HP".

With the aim to transform the energetic equivalents of two group of $\mathrm{N}$-free substrates into mass units of oxidizing substrates, the additional information of the mass or molar quantities may be used taking into account the absorption fluxes (Figure 1).

If all butyrate is oxidized to $\mathrm{CO}_{2}$ (including oxidation through ketone bodies), the mass quantity of oxidizing FFA may be estimated as follows: the daily absorption flux of butyrate is multiplied by $24.9 \mathrm{MJ} / \mathrm{kg}$, the value obtained is subtracted from energetic equivalent of FFA+butyrate and the rest is divided by $39 \mathrm{MJ} / \mathrm{kg}$ (the average combustion HP of the FFA mixture). Estimated daily oxidation losses of FFA include also those FFA that are formed in fat tissue de novo from acetate, liberated during lipolysis and entering into the circulation during the day. Taking into account the formation of FFA from acetate permits to match the data of RQ, mobilization of fat depots, oxidation of FFA to $\mathrm{CO}_{2}$ and milk components yield (see Figure 1 and algorithm of metabolic fluxes identification).

Approximately $50 \%$ of FFA contained in milk fat triacylglycerols are transported from the blood (mainly, as FFA formed from the blood triacylglycerols by the action of lipoprotein lipase localized on the capillary endothelium) and the rest is synthesized from acetate (Baldwin, 1987; Cherepanov et al., 2000). So, the balance of FFA fluxes consists of three components 


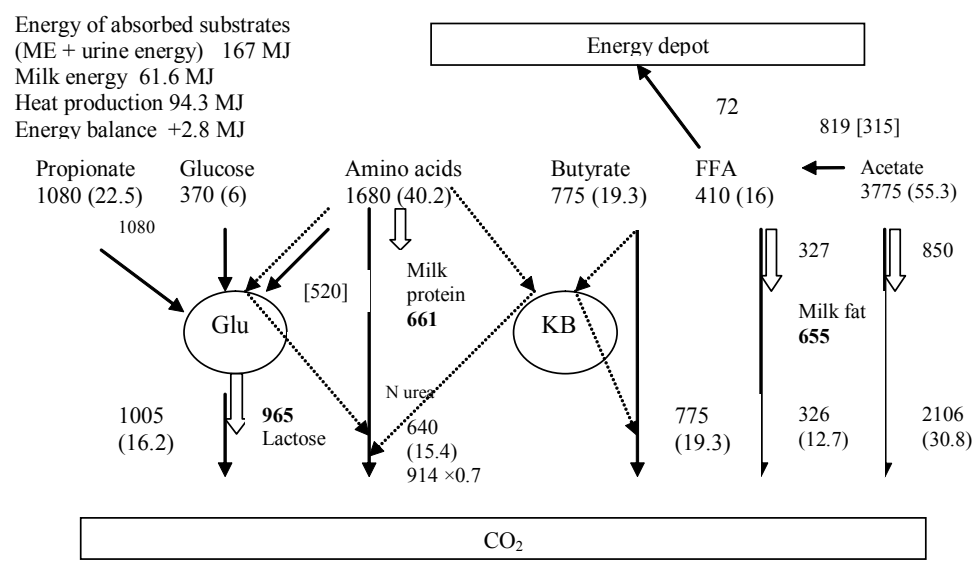

Figure 1. Flux diagram of interconversions, utilization for synthesis of milk components and oxidation to $\mathrm{CO}_{2}$ of main groups of substrates in cows of the control group during period 2 of the experiment (60-65 days in milk). Milk yield $20.1 \mathrm{~kg}$ (fat $3.26 \%$, protein $3.29 \%$ ), $\mathrm{RQ}=0.878$, liveweight $440 \mathrm{~kg}$. The arrows indicate fluxes of substrates. Numbers under designation of substrates are absorption or oxidation to $\mathrm{CO}_{2}$ fluxes, $\mathrm{g} / \mathrm{d}$ (in round brackets, $\mathrm{MJ} / \mathrm{d}$ ). Numbers near arrows indicate the utilization fluxes, $\mathrm{g} / \mathrm{d}$. Light arrows with thick numbers indicate production of milk components, $\mathrm{g} / \mathrm{d}$. Numbers in squared brackets are fluxes expressed in reference to product ( $\mathrm{g}$ of product/d). Dotted arrows indicate fluxes, heat effects of which are included in the energetic value of full oxidation to $\mathrm{CO}_{2}$

of influx (intestinal absorption, fat depot mobilization, daily synthesis from acetate) and two components of outflow (milk fat synthesis, oxidation to $\mathrm{CO}_{2}$ ). By equating the influx and outflow, the daily mass quantity of FFA is calculated that is synthesized from acetate. Since for the formation of $1 \mathrm{~g}$ of FFA approximately $2.6 \mathrm{~g}$ of acetate is needed on the average, by multiplying this value by 2.6, the daily utilization of acetate for the synthesis of FFA is calculated. Although lipogenesis from acetate takes place in fat tissue (fat depot), to gain a better understanding of the calculations performed, in the following diagram this flux is indicated as an arrow directed from acetate to the central pool of FFA.

By equating the acetate influx (absorption flux) and outflows (milk fat synthesis and oxidation), the daily quantity of oxidizing acetate $(\mathrm{g})$ is determined and then, using the value of heat effect of the oxidation of the second group of $\mathrm{N}$-free substrates (mainly, glucose+acetate), the daily quantity of oxidizing glucose (g) may be determined, if all propionate is metabolized through glucose formation (i.e. direct oxidation of propionate may be disregarded). For our experimental data this condition seems to be fulfilled, excluding group I (control), period I where a coefficient 0.8 was admitted for conversion of propionate to glucose. 
On the diagram presented in Figure 1, the absorption flux of amino acids is greater compared to the sum of utilization fluxes for net protein production, daily weight gain (not indicated in the diagram because it was small in this situation) and oxidation. By equating the influx and outflow of glucose, the daily utilization of amino acids for gluconeogenesis $(520 \mathrm{~g})$ is calculated taking into account that the daily glucose oxidation is equal to $1005 \mathrm{~g}$. This value includes oxidation of glucose in the mammary gland which on the average accounts for $30 \%$ of the total glucose uptake by the udder (Baldwin et al., 1987). Here it is assumed that approximately half of milk fat is synthesized from acetate and another half is originated from FFA.

\section{Algorithm of metabolic fluxes identification*}

1. The estimate of amino acids oxidation on the basis of daily excretion of urea- $\mathrm{N}$ with coefficient $0.7=914 \times 0.7=640 \mathrm{~g}$

2. Heat production from amino acids oxidation $=0.640 \times 24=15.4 \mathrm{MJ} ;(16 \%$ of $\mathrm{HP})$

3. «Non-protein $\mathrm{HP} »=94.3-15.4=78.9 \mathrm{MJ}$

4. $\mathrm{a}_{\text {FFA +but }}=3.33-3.33 \times 0.878=0.406$; HP of $($ FFA + butyrate $)$ oxidation $=0.406 \times 78.9=32 \mathrm{MJ}$

5. HP from FFA oxidation $=32-19.3=12.7(12700 / 39=326 \mathrm{~g})$

6. Utilization of FFA for fat accretion $=2800 / 39=72 \mathrm{~g}$

7. Utilization of FFA for (milk + oxidation + fat accretion $)=327+326+72=725 \mathrm{~g}$

8. Influx of FFA from acetate $=725-410=315 \mathrm{~g}$

9. Utilization of acetate for FFA synthesis $=315 \times 2.6=819 \mathrm{~g}$

10. Oxidation of acetate $=($ absorption -0.5 (milk fat) $2,6-$ synthesis of FFA $)=3775-850-819$ $=2106 \mathrm{~g}(\times 14.65=30.8 \mathrm{MJ})$

11. $\mathrm{HP}$ of (glucose + acetate) oxidation $=78.9-32=47 \mathrm{MJ}$

12. $\mathrm{HP}$ of glucose oxidation $=47-30.8=16.2 ;($ oxidation $=16200 / 16.12=1005 \mathrm{~g})$

13. Gluconeogenesis from amino acids $=$ (glucose oxidation $)+$ (lactose production $)-($ propionate flux $)$ - (glucose flux $)=1005+965-1080-370=520 \mathrm{~g}$

14. Utilization of amino acids for oxidation and synthesis of lactose $=1680-661=1019 \mathrm{~g}$

15. (Gluconeogenesis from amino acids)/(Utilization of amino acids for oxidation and synthesis of lactose) $=520 / 1019=0.5$

* The numerical values are taken from Figure 1. The values of fluxes are expressed on daily basis, i.e. in $\mathrm{g}$

In this paper we do not analyse in detail the differences between control and experimental groups. This was done partly in cited paper (Agaphonov and Denkin, 2009). The prime goal was to develop the computational algorithm and verify it by comparing the results obtained with existing data. The values of parameters estimated with the use of this algorithm and summarized in Table 6 are in agreement with averaged values reported in the literature. Efficiency of absorbed amino acid utilization for milk protein synthesis is in the range of 
Table 6. Estimated values of metabolic fluxes for 2 groups of cows and 3 periods

\begin{tabular}{|c|c|c|c|c|c|c|c|c|c|c|c|}
\hline \multirow{3}{*}{$\begin{array}{l}\text { Periods, } \\
\text { Groups }^{1}\end{array}$} & \multicolumn{10}{|c|}{ Oxidation to $\mathrm{CO}_{2}$} & \multirow{3}{*}{$\begin{array}{l}\begin{array}{l}\text { GNG from } \\
\text { amino acid }\end{array} \\
\mathrm{g} / \mathrm{d}\end{array}$} \\
\hline & \multicolumn{2}{|c|}{ acetate } & \multicolumn{2}{|c|}{ glucose } & \multicolumn{2}{|c|}{ FFA } & \multicolumn{2}{|c|}{ butyrate } & \multicolumn{2}{|c|}{ amino acids } & \\
\hline & $\mathrm{g} / \mathrm{d}$ & $\%^{2}$ & $\mathrm{~g} / \mathrm{d}$ & $\%$ & $\mathrm{~g} / \mathrm{d}$ & $\%$ & $\mathrm{~g} / \mathrm{d}$ & $\%$ & $\mathrm{~g} / \mathrm{d}$ & $\%$ & \\
\hline 1 - control & 1872 & 29 & 900 & 16 & 405 & 17 & 708 & 19 & 700 & 18 & - \\
\hline 1 - experimental & 2091 & 32 & 909 & 15 & 388 & 16 & 763 & 20 & 689 & 17 & 187 \\
\hline 2 - control & 2168 & 33 & 1005 & 17 & 326 & 13 & 775 & 20 & 640 & 16 & 520 \\
\hline 2 - experimental & 1745 & 26 & 1054 & 17 & 520 & 20 & 890 & 22 & 626 & 15 & 227 \\
\hline 3 - control & 1154 & 17 & 1309 & 21 & 405 & 16 & 1110 & 28 & 700 & 17 & 503 \\
\hline 3 - experimental & 1367 & 19 & 1241 & 19 & 497 & 18 & 1290 & 30 & 681 & 15 & 416 \\
\hline
\end{tabular}

${ }^{1}$ periods: 1 - 40-45; 2 - 60-65; 3 - 90-95 days in milk. GNG - gluconeogenesis; ${ }^{2}$ percent of total heat production

42-57\% (Oldham, 1980); our estimates are 39-52\%. Amino acids utilization for gluconeogenesis and oxidation in the cow, after recalculation for liveweight 450 $\mathrm{kg}$, is in the range of 900-1350 $\mathrm{g}$ (Riis, 1983); our estimates are $850-1200 \mathrm{~g}$. The contribution of amino acids into gluconeogenesis in cow's liver varies is in the range of $12-40 \%$ (Madsen, 1983). The contribution of acetate into total HP in lactating cows varies in the range of $19-34 \%$ (the percent contribution into total $\mathrm{CO}_{2}$ production; Giesecke, 1983); our estimates are 17-33\%. Acetate oxidation in the cows with daily milk yield of $30 \mathrm{~kg}$ are estimated in the range of 1400-1900 $\mathrm{g} / \mathrm{d}$; glucose oxidation: $800-1100 \mathrm{~g} / \mathrm{d}$; FFA: $350-500 \mathrm{~g} / \mathrm{d}$ (Baldwin and Smith, 1983); our estimates are 1100-2200, 900-1300, 330-500 g/d, respectively. The analysis of combined data ( 2 groups, 3 periods) revealed a negative correlation between daily oxidation of glucose and acetate $(\mathrm{r}=0.91)$ and between two groups of substrates (FFA + butyrate) and (glucose + acetate) $(\mathrm{r}=0.75$; Figure 2).
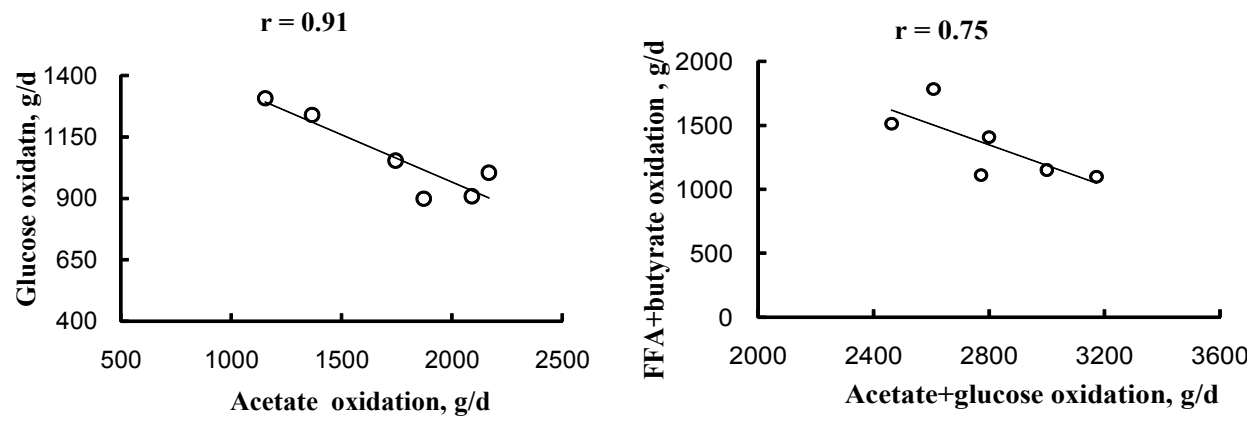

Figure 2. Correlations of oxidation fluxes between glucose and acetate $(\mathrm{r}=0.91)$ and between two groups of substrates: (FFA + butyrate) and (acetate + glucose $)(r=0.75)$. Combined data for 2 groups of cows and 3 experimental periods (40-45; 60-65; 90-95 days in milk) 
The reciprocal relationships between rates of utilization of various substrates were described by several authors in the literature. For example, the oxidation of glucose in the cells of mammary gland was decreased at elevated level of acetate (Forsberg et al., 1985; Baldwin et al., 1987). The deficit of glucose usually causes the elevated oxidation of FFA in ruminants (Giesecke, 1983).

So, the results obtained suggest that estimated values of metabolic and energetic fluxes do agree with existing experimental data, at least at the level of accuracy of the measurements made in vivo on lactating ruminants.

\section{CONCLUSIONS}

This paper describes a first attempt to construct the basic metabolic fluxes in lactating cows using experimental data of substrates absorption, heat production, respiratory quotient and productive parameters. Taking into account the difficulties and problems associated with measurements of the absorption fluxes and in the interpretation of respiratory data, the crucial point was whether or not a mutually consistent metabolic flux pattern could be constructed on the basis of data obtained in vivo. As a whole, the results obtained give a positive answer to this question. In turn, if we can obtain such a mutually consistent balance diagram, we can estimate, through its use, those parameters which can be measured experimentally only with very great (practically insuperable) difficulties, for example, oxidation rates of substrates and their interconversions (synthesis FFA from acetate, gluconeogenesis from amino acids, etc.). The possible inaccuracies in these estimates, due to biases in the determination of amino acids oxidation and other factors, have undoubtedly to be decreased in subsequent investigations. The data obtained suggest that traditional physiological approaches to estimation of metabolic state in lactating cows may be refined using additional respiratory measurements and methods of parametric identification.

\section{REFERENCES}

Agaphonov V.I., 1998. Energy and substrate estimates of the nutritional value of ruminant diets. In: P. Junghans, M. Beyer, W. Hackl (Editors). Energetic Feed Evaluation and Regulation of the Nutrient and Energy Metabolism in Farm Animals. International Symposium, Rostock (Germany), pp. 69-70

Agaphonov V.I., Denkin A.I., 2009. Lung gas exchange and the quantitative aspects of substrates utilization in the cow's energetic metabolism in early lactation. Probl. Biol. Prod. Anim. (Russia) 1, 67-76

Baldwin R.L., Bywater A.C., 1984. Nutritional energetics of animals. Annu. Rev. Nutr. 4, 101-114 
Baldwin R.L., France J., Gill M., 1987. Metabolism of the lactating cow. I. Animal elements of a mechanistic model. J. Dairy Res. 54, 77-108

Baldwin R.L., Smith N.E., 1983. Adaptation of metabolism to various conditions: Milk production. In: P.M. Riis (Editor). Dynamic Biochemistry of Farm Animals. Elsevier, Amsterdam, pp. 359388

Black A.L., Anand R.C., Bruss M.L., Brown C.A., Nakagiri J.A., 1990. Partitioning of amino acids in lactating cows: oxidation to $\mathrm{CO}_{2}$. J. Nutr. 120, 700-710

Brosh A., 2008. Heart rate measurements as an index of energy expenditure and energy balance in ruminants: A review. J. Anim. Sci. 85, 1213-1227

Cherepanov G.G., Danfaer A., Cant J.P., 2000. Simulation analysis of substrate utilization in the mammary gland of lactating cow. J. Dairy Res. 67, 171-188

Danfaer A., 1990. A dynamic model of nutrient digestion and metabolism in lactating dairy cows. 671 Report of National Institute of Animal Science, Kopenhagen (Denmark), p. 397

Forsberg N.E., Baldwin R.L., Smith N.E., 1985. Role of glucose and its interactions with acetate in maintenance and biosynthesis in bovine mammary tissue. J. Dairy Sci. 67, 2444-2549

Giesecke D., 1983. The pools of cellular nutrients: Plasma free fatty acids. In: P.M. Riis (Editor). Dynamic Biochemistry of Farm Animals. Elsevier, Amsterdam, pp. 197-214

Hanigan M.D., Crompton L.A., Reynolds C.K., Wray-Cahen D., Lomax M.A., France J., 2004. An integrative model of amino acid metabolism in the liver of the lactating dairy cow. J. Theor. Biol. 228, 271-289

Huntington G.B., Zetina E.J., Whitt J.M., Potts W., 1996. Effects of dietary concentrate level on nutrient absorption, liver metabolism, and urea kinetics of beef steers fed isonitrogenous and isoenergetic diets. J. Anim. Sci. 74, 908-916

Madsen A., 1983. The molecular basis of animal production: Metabolism in liver cells. In: P.M. Riis (Editor). Dynamic Biochemistry of Farm Animals. Elsevier, Amsterdam, pp. 53-74

Oldham J.D., 1980. Amino acid requirements for lactation in high-yielding dairy cows. In: Recent Advances in Animal Nutrition. Butterworths, London, pp. 33-65

Riis P.M., 1983. The pools of cellular nutrients: Amino acids. In: P.M. Riis (Editor). Dynamic Biochemistry of Farm Animals. Elsevier, Amsterdam, pp. 151-173

Riis P.M., Danfaer A., Hvelplund T., Madsen A., Nielsen M.O., Petersen P.H., Sejrsen K., Thilsted Sh.H., 1990. A model for the efficient use of new information within physiology, nutrition and breeding of dairy cows. 666 Report of National Institute of Animal Science, Kopenhagen (Denmark), p. 70

Tan Z., Murphy M.R., 2004. Ammonia production, ammonia absorption, and urea recycling in ruminants. A review. J. Anim. Feed Sci. 13, 389-404

Whitt J., Huntington G., Zetina E., Casse E., Taniguchi K., Potts W., 1996. Plasma flow and net nutrient flux across gut and liver of cattle fed twice daily. J. Anim. Sci. 74, 2450-2461 